\title{
Graphical Abstracts
}

\section{C-Terminal Truncation of $\alpha \mathbf{1 , 6 - f u c o s y l t r a n s f e r a s e ~ f r o m ~}$}

\section{Rhizobium Sp. does not Annul the Transferase Activity of the Enzyme}

Agatha Bastida, Alfonso Fernández-Mayoralas and Eduardo García-Junceda*

Departamento de Química Orgánica Biológica, Instituto de Química Orgánica General, CSIC, Madrid 28006, Spain

Deletion of a C-terminal fragment including a putative transmembrane-like region of the $\alpha 1$,6-FucT from Rhizobium sp. led to a mutant enzyme retaining the main catalytic and specificity features of the wild-type enzyme. However, such truncation allowed us to obtain higher yields of soluble transferase per unit of biomass and with improved stability in solution, which represent a significant advantage.

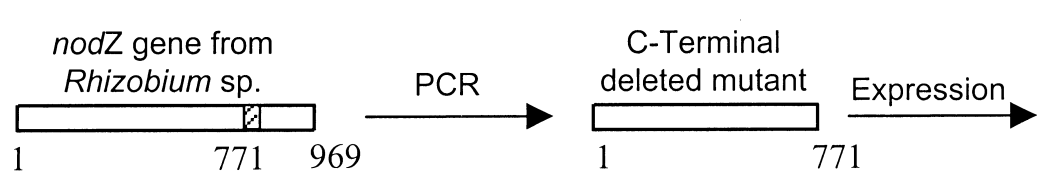
$\alpha 1,6-$ FucT soluble ( $9 \mathrm{U} / \mathrm{L}$ of culture)

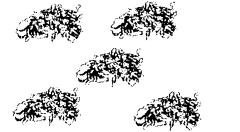




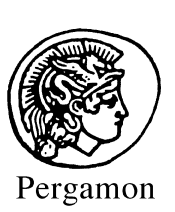

BIOORGANIC \&

Bioorganic \& Medicinal Chemistry $\square(\square \square \square \square) \square-\square$

*Corresponding author. Tel.: +34-91-562-2900; fax: +34-91-5644853; e-mail: iqogj78@fresno.csic.ed heterologous system the enzyme was mainly expressed as inclusion bodies. Several attempts to refold the protein solubilizing the pellet with urea or guanidine, followed by a slow elimination of the denaturant agent by dialysis against buffer were unsuccessful. Use of different folding aids in the dialysis buffer, ${ }^{6}$ including glycidol, Triton X-100, Tween-20 and polyethylene glycol (PEG) with the same unfruitful result. Additionally, the enzyme expressed in soluble form lost the activity after few days due to precipitation of the protein. In view of these results, we performed a computational analysis of the secondary structure of the enzyme. The TMpred program $^{7}$ predicted a transmembrane-like region of 19 aa close to the C-terminal of the protein.

In this paper, we report the cloning of a truncated version of the protein where a C-terminal fragment of 65 aa, including the predicted hydrophobic region, has been removed. The influence of this region on the formation of inclusion bodies and precipitation of the wildtype enzyme has been investigated. We compared the kinetic behavior of the truncated $\alpha$ 1,6-fucosyltransferase $(\alpha 1,6$-FucT) with the wild-type enzyme as well as the acceptor specificity. Some structural features are also discussed. 


\section{Results}

\section{C-terminal truncation of $\alpha \mathbf{1 , 6 - f u c o s y l t r a n s f e r a s e ~}$}

We performed a computational prediction of the secondary structure of the $\alpha 1,6-\mathrm{FucT}$ (Fig. 1) in order to detect some structural characteristics that could be responsible for the tendency of the enzyme to precipitate. The TMpred program ${ }^{7}$ identifies potential highly hydrophobic segments in proteins suggesting that they could participate in protein-membrane interactions. This program showed three possible transmembrane-like helices in the sequence of $\alpha 1,6$-FucT from Rhizobium sp., but only one, between the amino acids 258 and 276, could be considered significant. The 'DAS'-Transmembrane Prediction server ${ }^{8}$ also predicted a transmembrane-like segment of 13 aa between the residues 265 and 277. As the predicted hydrophobic region was close to the $\mathrm{C}$-terminal, we decided to remove the fragment comprised from the residue 258 to the C-terminal amino acid (Fig. 1). This fragment included an $\alpha$-helix of 11 aa corresponding to the transmembrane-like segment and three short segments of 3,4 and 6 residues, respectively, with potential $\beta$ sheets structure. On the other hand, the expected isoelectric point (5.39) is not significantly changed with respect to the non-truncated enzyme (5.32).

The truncation of the nodZ gene from Rhizobium sp. was performed by PCR. The leftward primer contained $15 \mathrm{bp}$ of the $5^{\prime}$ end of the coding DNA strain and the sequence for the restriction enzyme Eco RI. The rightward primer was designed to complement $15 \mathrm{bp}$ from nucleotide 757-771 of the coding strain; the stop codon TGA and the recognition sequence for Hind III were also included (Fig. 2). The PCR amplification was quite specific, and only one band with the expected length (771 bp) was observed. The band was purified and double digested with the above mentioned restriction enzymes and ligated with the digested vector pKK223-3. The main features of the resulting expression vector (pK1,6FucTDS) are shown in Figure 2. The pK1,6FucTDS plasmid was transformed in E. coli XL1Blue $\mathrm{MRF}^{\prime}$ strain and plated on LB-ampicillin plates. The presence of the truncated gene in the transformed cells was checked by restriction analysis of the purified plasmids. Out of 10 colonies selected, nine carried the desired insert. One positive colony was grown on LB medium containing $250 \mu \mathrm{g} / \mathrm{mL}$ ampicillin and induced with $1 \mathrm{mM}$ of isopropyl- $\beta$-D-thiogalactopyranoside (IPTG) when the O.D. at $600 \mathrm{~nm}$ raised 0.5. The expression of the recombinant enzyme was analysed by sodium dodecyl sulphate-polyacrilamide gel electrophoresis (SDS-PAGE) from samples taken 3, 5 and $24 \mathrm{~h}$ after induction.

In all cases, an IPTG induced band, matching the expected molecular weight $(29.5 \mathrm{kD})$, was only observed in the soluble fraction and formation of inclusion bodies was not observed. This soluble fraction showed transferase activity upon the spectrophotometric assay. ${ }^{9}$ The production of mutant enzyme per liter of culture was about $9 \mathrm{U}$, almost double the previously reported yield for the wild-type enzyme. ${ }^{5}$

The possible loss of activity of the truncated enzyme in solution was tested and compared with that of the wildtype enzyme (Fig. 3). The activity of the latter was completely lost after 5 days at $4{ }^{\circ} \mathrm{C}$ with a half-life of 2 days, due to enzyme precipitation. The deletion of the $\mathrm{C}$-terminal fragment resulted in a significant increase of

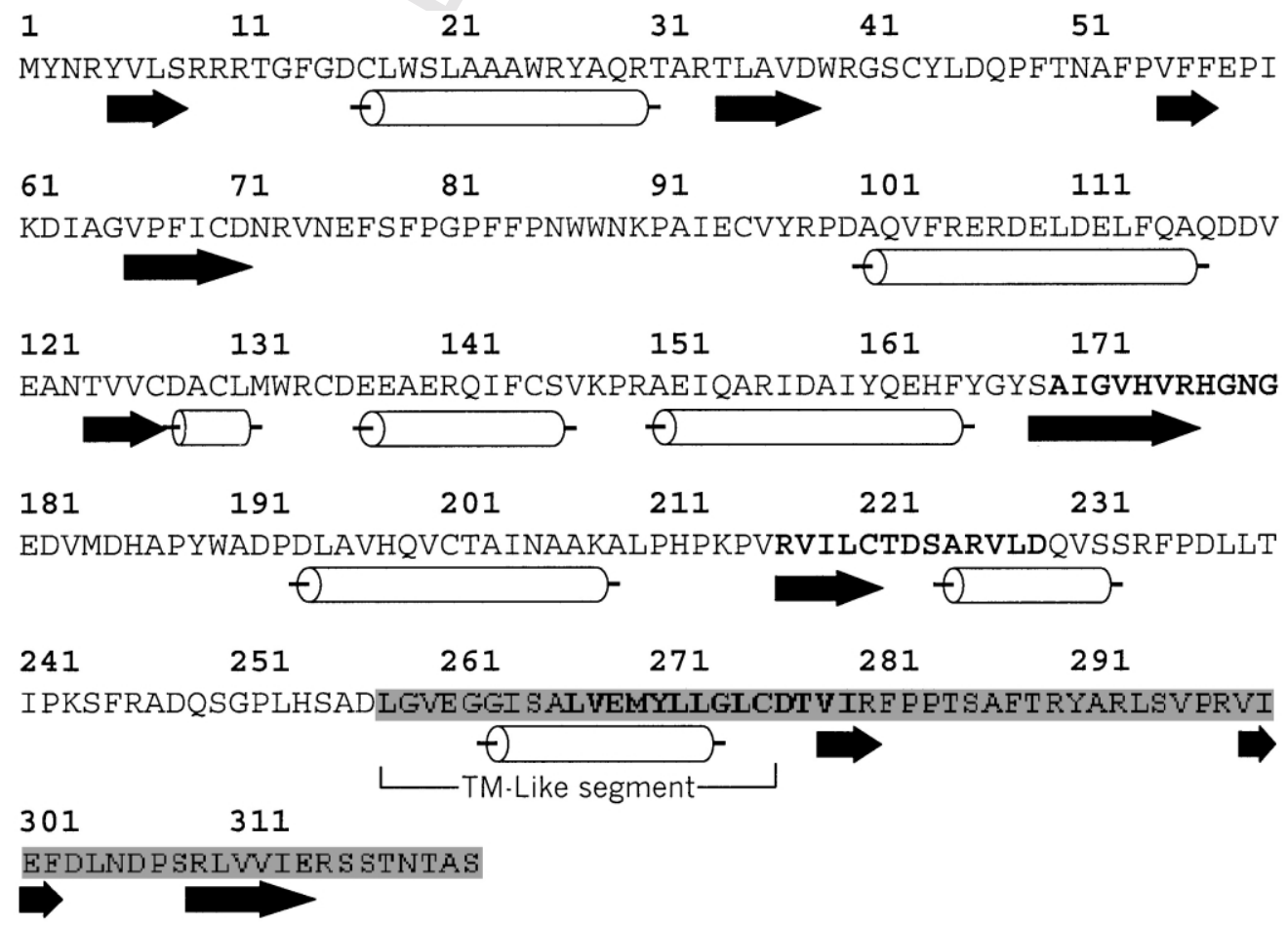

Figure 1. Sequence and predicted secondary structure of the $\alpha$ 1,6-FucT from Rhizobium sp. Gray area represent the deleted fragment in the truncated enzyme. Transmembrane-like region is indicated. Bold letters represent the conserved $\alpha$-6-motifs. $\bigcirc-\alpha$-Helix. $\Rightarrow \beta$-Sheets. 

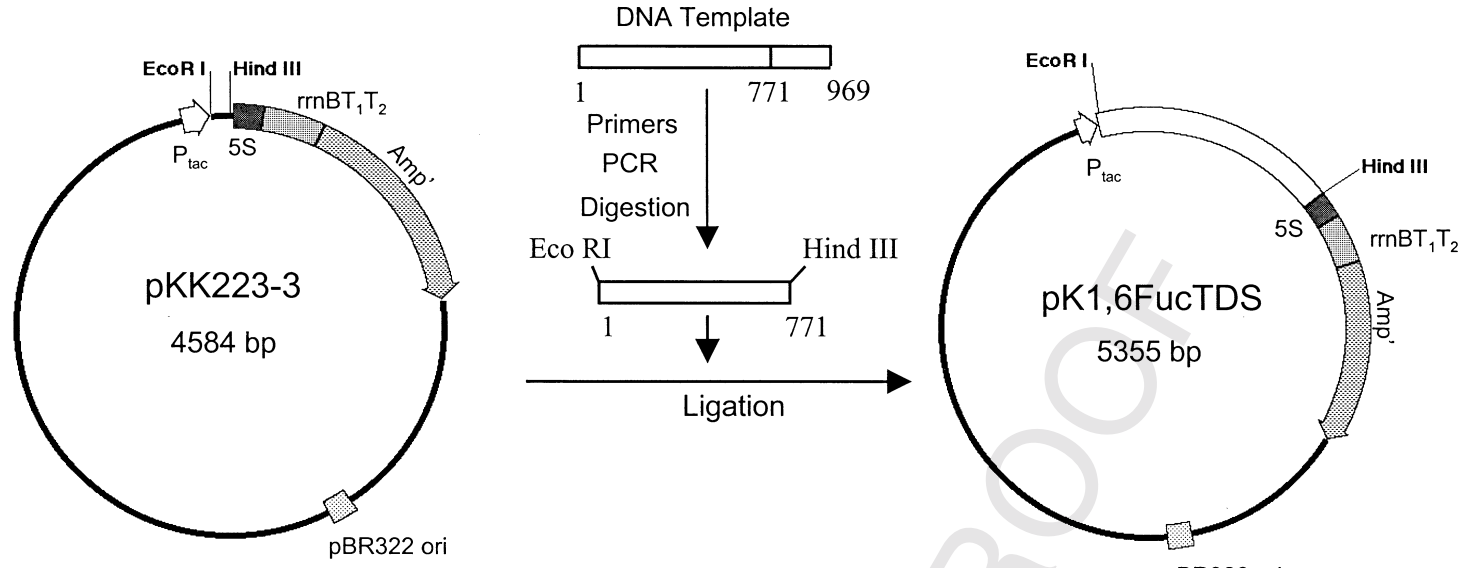

pBR322 ori

Figure 2. Construction of the expression plasmid for the C-terminal truncated $\alpha$ 1,6-FucT. The main characteristics of the vector are shown. The sequence of the primers used for the PCR were as follows: leftward primer $5^{\prime}$-GCCGCGAATTCATGTACAATCGATAT-3'; rightward primer 5' CGCGCAAGCTTTCAATCTGCGCTGTGTAA-3'.

the enzyme stability, since after 5 days the truncated enzyme retained almost the $100 \%$ of the activity and no protein precipitation was observed.

\section{Kinetic and acceptor specificity studies}

Although the truncated $\alpha$ 1,6-FucT retained the transferase activity, other catalytic properties, such as the specificity for substrate, could be affected by the elimination of the C-terminal peptide. Thus, we evaluated the influence of the deletion on the specificity for donor and acceptor substrates by analysing the kinetic for donor (GDP- $\beta$-L-fucose) at fixed concentration of chitobiose and using different mono- and oligosaccharides as acceptors, respectively.

The kinetic parameters $K_{\mathrm{M}}$ and $V_{\max }$ were obtained from the plot of $[\mathrm{s}] / v$ versus $[\mathrm{s}]$ (Table 1). This straightline plot [eq (2)] is generated by multiplying both sides of the double-reciprocal equation [eqn (1)] by [s].

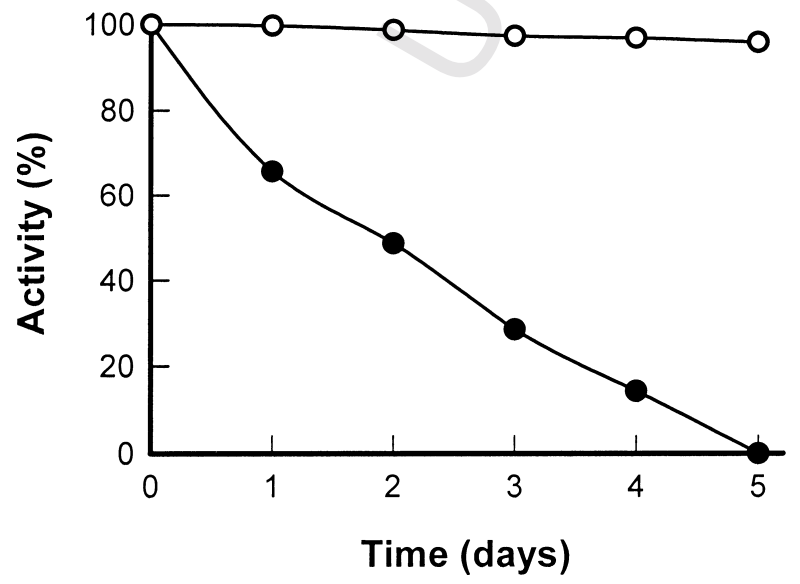

Figure 3. Stability of wild-type $(\mathbf{O})$ and truncated $(\bigcirc) \propto 1,6$ FucT in solution at $4{ }^{\circ} \mathrm{C}$. Activity was measured using GDP-Fuc $(50 \mu \mathrm{M})$ as donor and chitobiose $(100 \mu \mathrm{M})$ as acceptor.

$$
\begin{aligned}
& \frac{1}{v}=\frac{1}{V_{\max }}+\frac{K_{\mathrm{M}}}{V_{\max }[\mathrm{s}]} \\
& \frac{1}{v}=\frac{1}{V_{\max }} \cdot[\mathrm{s}] \frac{K_{\mathrm{M}}}{V_{\max }}
\end{aligned}
$$

In this plot, known also as Hanes plot or Woolf plot, the slope of the straight-line is equal to $K_{\mathrm{M}} / V_{\max }$ and the abscissa intercept is equal to $-K_{\mathrm{M}}$. The [s] $/ v$ against [s] plot has the advantage over the most popular doublereciprocal plot in that the distribution of the errors is more homogeneous along the straight-line, giving more accurate results. ${ }^{10}$

The truncation of the C-terminal fragment led to different kinetic parameters between the mutant and the wildtype enzymes (Table 1). The truncated $\alpha$ 1,6-FucT showed a 4.5-fold lower apparent $K_{\mathrm{M}}$, indicating a higher affinity for the GDP-Fuc. The apparent $V_{\max }$ also decreased after truncation from 0.58 to 0.135 $\mu \mathrm{M} \cdot \mathrm{min}^{-1} \cdot \mathrm{mg}^{-1}$ protein. Interestingly, the catalytic efficiency $\left(V_{\max } / K_{\mathrm{M}}\right)$ was not affected by the C-terminal deletion (Table 1).

We have also investigated if the acceptor specificity was modified by the enzyme truncation. In Table 2 , the results obtained with the mutant and the wild-type $\alpha$ 1,6-FucT enzymes are summarized.

Table 1. Apparent kinetic parameters of wild-type and C-terminal truncated $\alpha$ 1,6-FucT for GDP-Fuc

\begin{tabular}{lccc}
\hline Enzyme & $K_{\mathrm{M}}(\mu \mathrm{M})$ & $\begin{array}{c}V_{\max } \\
\left(\mu \mathrm{M} \mathrm{min} \mathrm{mg}^{-1} \text { protein }\right)\end{array}$ & $V_{\max } / K_{\mathrm{M}}$ \\
\hline Wild-type & 72.12 & 0.58 & 0.0080 \\
Mutant & 15.79 & 0.13 & 0.0085 \\
\hline
\end{tabular}

Parameters were determined in the presence of $100 \mu \mathrm{M}$ of chitobiose as acceptor substrate. 
Table 2. Comparison of the acceptor specificity of wild-type and truncated $\alpha 1,6$-FucT using GDP- $\beta$-L-fucose as donor

\begin{tabular}{|c|c|c|}
\hline \multirow[t]{2}{*}{ Acceptor } & \multicolumn{2}{|c|}{$V_{\text {rel }}(\%)^{\mathrm{a}}$} \\
\hline & W-T & Mutant \\
\hline \multicolumn{3}{|l|}{ Chitin oligomers } \\
\hline$[\text { GlcNAc } \beta 1 \rightarrow 4]_{2}(\mathbf{1})$ & 100 & 100 \\
\hline$[\mathrm{GlcNAc} \beta 1 \rightarrow 4]_{3}(2)$ & 106 & 114 \\
\hline$[\mathrm{GlcNAc} \beta 1 \rightarrow 4]_{4}(3)$ & 126 & 170 \\
\hline \multicolumn{3}{|l|}{ Di- and trisaccharides } \\
\hline $\operatorname{Gal} \beta(1 \rightarrow 4)$ GlcNAc $(4)$ & $56^{\mathrm{b}}$ & 56 \\
\hline Fuc $\alpha(1 \rightarrow 3)$ GlcNAc $\beta-O P r(5)$ & $31^{\mathrm{b}}$ & 27 \\
\hline S-Fuc $\alpha(1 \rightarrow 3)$ GlcNÁc $\beta-O B n(6)$ & $36^{\mathrm{b}}$ & 32 \\
\hline $\operatorname{Gal} \beta(1 \rightarrow 4)[$ S-Fuc $\alpha(1 \rightarrow 3)]$ GlcNAc $\beta-O B n(7)$ & $0^{\mathrm{b}}$ & 11 \\
\hline \multicolumn{3}{|l|}{ Monosaccharides } \\
\hline GlcNAc (8) & $18^{\mathrm{b}}$ & 36 \\
\hline GlcNAc $\beta-O M e(9)$ & $39^{\mathrm{b}}$ & 42 \\
\hline GlcNAc $\beta-O B n(10)$ & $51^{\mathrm{b}}$ & 56 \\
\hline GlcNAc $\alpha-O B n(11)$ & $53^{\mathrm{b}}$ & 51 \\
\hline GlcNAcß-OSiMe (12) & $0^{\mathrm{b}}$ & 0 \\
\hline $\mathrm{GlcNH}_{2}(\mathbf{1 3})$ & $18^{\mathrm{b}}$ & 25 \\
\hline Glc (14) & $9^{\mathrm{b}}$ & 12 \\
\hline ManNAc (15) & $12^{\mathrm{b}}$ & 23 \\
\hline GalNAc (16) & $9^{\mathrm{b}}$ & 21 \\
\hline
\end{tabular}

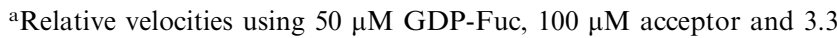
$\mathrm{mU}$ of enzyme. The values are referred to the reaction rate with chitobiose.

${ }^{\mathrm{b}}$ Data taken from ref 5 .

As in the case of the wild-type enzyme, the truncated $\alpha$ 1,6-FucT showed a broad specificity for the acceptor substrate although some appreciable differences can be outlined. Previously reported data have shown that the $\alpha$ 1,6-FucT's from Rhizobium sp. ${ }^{11}$ and Bradyrhizobium japonicum ${ }^{12}$ can fucosylate di-, tri-, tetra-, penta- and hexa-chitin oligomers, showing the highest rates with the penta- and hexasaccharides. The truncated enzyme showed an even higher preference for long chitin oligomers than the wild-type. Thus, while the activity of the wild-type enzyme increased $26 \%$ from chitobiose (1) to chitotetraose (3), the activity of the mutant raised to $170 \%$ (Table 2). A significant difference in $V_{\text {rel }}$ was also observed in the fucosylation of the monosaccharide GlcNAc (8), being the truncated enzyme two times more efficient than the wild-type. However, no difference was observed for the glycosides of GlcNAc 9-12. A remarkable result was the observation that the mutant enzyme accepted the branched trisaccharide $\mathbf{7}$, which, is not a substrate for the wild-type fucosyltransferase. Other monosaccharides, such as Glc (14), ManNAc (15) and GalNAc(16) were substrates of the mutant with higher $V_{\text {rel }}$ than the wild-type enzyme. However, the decrease of the reaction rate with respect to GlcNAc (8) promoted by the axial position of the NHAc group of $\mathbf{1 5}$ and the galacto configuration of C-4 of $\mathbf{1 6}$ was similar for the wild-type and the mutant enzymes and therefore, it is unclear if the influence of these changes is different in both enzymes.

\section{Discussion}

We have cloned and expressed a C-terminal truncated mutant of the $\alpha 1,6$ FucT from Rhizobium sp. From the data obtained, we can make some comments about the location of the active site of the enzyme. Although it is generally accepted that in mammalian glycosyltransferases the active center is located in the $\mathrm{C}$-terminal portion of the enzyme, ${ }^{13}$ some data point out that in other organisms this situation could be different. For example, recently it has been reported that a $\mathrm{N}$-terminal truncated $\alpha 1,2$ FucT from Helicobacter pylori showed no activity. ${ }^{14}$ Therefore, the main objective of the present work was to test if by deleting the C-terminal fragment containing the predicted transmembrane-like region, an improvement of the expression and stability in solution of the $\alpha 1,6$ FucT could be achieved without losing the transferase activity. This hypothesis has been confirmed by the results obtained. The mutant protein showed transferase activity and it was expressed exclusively in soluble form. The influence of the highly hydrophobic segment on the low stability in solution of the wild-type enzyme was also confirmed since the mutant did not lose activity after 5 days at $4{ }^{\circ} \mathrm{C}$ and no protein precipitation was observed (Fig. 3).

Oriol et al., ${ }^{15}$ using hydrophobic cluster analysis (HCA) defined three peptide motifs, which are conserved in $\alpha$ 1,6-fucosyltransferases found in vertebrates, invertebrates and bacteria. The $\alpha-6$-motifs I and II are shared by eukaryotic and prokaryotic $\alpha 1,2$-fucosyltransferases, whereas the $\alpha$-6-motif III is specific of the $\alpha 1,6$ family. ${ }^{15,16}$ The $\alpha$-6-motif III of the Rhizobium sp. $\alpha$ 1,6 FucT is found in the fragment that was deleted in our mutant enzyme (Fig. 1). Therefore, our results show that this motif is not essential for the activity of the enzyme, although it remains unclear whether it can play any role in the donor and/or acceptor substrates binding. On the other hand, it has been recently demonstrated that the Arg-365 of the human $\alpha$ 1,6 FucT is essential for the enzyme activity, participating in both the catalysis and the binding of the donor substrate. ${ }^{17}$ This residue belongs to the $\alpha$-6-motif $I$ and in the sequence of the Rhizobium enzyme corresponds to the Arg-176.

The C-terminal truncation of the $\alpha 1,6$ FucT did not change drastically the specificity towards the acceptor substrate. However, the branched thio-trisaccharide Gal $\beta 1 \rightarrow 4[$ S-Fuc $\alpha(1 \rightarrow 3)]$ GlcNAc $\beta$-OBn (7), which was not substrate for the wild-type enzyme possibly due to steric hindrance, was accepted by the mutant transferase (Table 2) although at a low rate. This result suggests that the acceptor substrate binding site could be wider or more flexible in the truncated $\alpha 1,6$ FucT than in the wild-type enzyme. This higher flexibility could also account for the higher reaction rates showed by the truncated enzyme with chitotetraose (3). Higher versatility in the binding modes of the truncated enzyme could also be the origin of certain levels of non-productive binding as suggest the apparently lower values of $K_{\mathrm{M}}$ and $V_{\max }$ for the mutant compared with the wild-type enzyme towards GDP-Fuc (Table 1).

On the other hand, it is noteworthy that both the wildtype and the truncated $\alpha 1,6$ FucT are able to fucosylate the $\alpha$ and the $\beta$ benzyl glycosides of GlcNAc with 
similar reaction rates (10 and $\mathbf{1 1}$, Table 2). The lack of selectivity for the anomeric configuration of the acceptor seems to be a general feature of bacterial glycosyltransferases, since a similar behaviour has been described for the $\alpha 2,3$-sialyltransferase ${ }^{4 \mathrm{c}}$ and the $\beta 1,3-$ $\mathrm{N}$-acetylglucosaminyltransferase, ${ }^{4 \mathrm{~d}}$ both from Neisseria meningitidis.

\section{Conclusion}

In conclusion, we have shown that the deletion of a Cterminal fragment of the $\alpha 1,6-\mathrm{FucT}$ from Rhizobium $\mathrm{sp}$. led to a mutant enzyme retaining the catalytic and specificity features. However, such truncation allowed us to obtain higher yields of soluble transferase per unit of biomass and with improved stability in solution, which represent a significant advantage. Work is in progress for a more detailed kinetic characterization of both wild-type and mutant fucosyltransferases.

\section{Experimental}

\section{Materials}

Rhizobium sp. NG234R strain was provided from the Microbiology Laboratory, ETSIA, Universidad Politécnica de Madrid (Spain). E. coli competent cells XL1Blue MRF' were purchased from Stratagene Co. (San Diego, CA, USA). pKK223-3 vector was obtained from Pharmacia Biotech. Inc.(Piscataway, NJ, USA). Taq DNA polymerase was purchased from Ecogen (Spain). T4 DNA ligase was obtained from MBI Fermentas AB (Lithuania). Restriction enzymes Eco RI and Hind III were purchased from Boehringer Manheim (Germany). IPTG was purchased from Applichem GmBH (Germany). Pyruvate kinase type II from rabbit muscle, Llactic dehydrogenase type II from rabbit muscle, phosphoenol pyruvic acid (PEP), $\beta$-NADH, GlcNAc, $\mathrm{GlcNH}_{2}$, Glc, ManNAc and GalNAc were obtained from Sigma St. Louis, MO). $N, N^{\prime}$-Diacetylchitobiose, $N, N^{\prime}, N^{\prime \prime}$-triacetylchitobiose, $\quad N, N^{\prime}, N^{\prime \prime}, N^{\prime \prime \prime}$-tetraacetylchitobiose, and $N$-acetyllactosamine were obtained from Toronto Research Chemicals (Ontario, Canada). GDPFuc was purchased from Oxford GlycoSciences (UK). The oligosaccharides Fuc $\alpha(1 \rightarrow 3)$ GlcNAc $\beta-O P r, \quad$ SFuc $\alpha(1 \rightarrow 3)$ GlcNAc $\beta-O B n, \quad \operatorname{Gal} \beta(1 \rightarrow 4)[\mathrm{S}-\mathrm{Fuc} \alpha(1 \rightarrow 3)]$ GlcNAc $\beta-O B n, \quad$ GlcNAc $\beta-O S i M e, \quad$ GlcNAc $\beta-O M e$, GlcNAc $\alpha-O B n$ and GlcNAc $\beta-O B n$ were previously synthesized in our laboratory. ${ }^{18}$ All other chemicals were purchased from commercial sources as reagent grade.

\section{C-Terminal truncation}

C-terminal truncation of the $\alpha$ 1,6-FucT from Rhizobium $\mathrm{sp}$. was performed by PCR. The rightward primer was designed to complement $15 \mathrm{bp}$ from nucleotide 757 to 771 of the coding strain, the stop codon TGA and the recognition sequence for Hind III were also included. DNA of Rhizobium sp. was used as template. The oligonucleotides 5'-GCCGCGAATTCATGTACAAT-
CGATAT- $3^{\prime}$ and 5'-CGCGCAAGCTTTCAATCTGCGCTGTGTAA- $3^{\prime}$ were used as leftward and rightward primers respectively. PCR amplification was performed in a $100 \mu \mathrm{L}$ reaction mixture containing $3 \mu \mathrm{L}$ of DNA template, $70.5 \mu \mathrm{L}$ of water, $10 \mu \mathrm{L}$ of $10 \times$ buffer $(100 \mathrm{mM}$ Tris-HCL, $500 \mathrm{mM} \mathrm{KCl}, \mathrm{pH}=8.0), 2 \mathrm{mM}$ $\mathrm{MgCl}_{2}, 200 \mu \mathrm{M}$ of dNTPs, $1 \mu \mathrm{M}$ of primers and $2.5 \mathrm{U}$ of Taq DNA polymerase. The reaction was subjected to 30 cycles of amplifications. The cycle conditions were set as follows: denaturation at $94^{\circ} \mathrm{C}$ for $1 \mathrm{~min}$, annealing at $55^{\circ} \mathrm{C}$ for $1.5 \mathrm{~min}$, and elongation at $72{ }^{\circ} \mathrm{C}$ for $1 \mathrm{~min}$.

\section{Construction of the pK1,6FucTDS expression vector}

The $771 \mathrm{bp}$ band obtained from the PCR was purified with the Wizard PCR Preps DNA Purification System (Promega; Madison, WI, USA). The insert and the pKK223-3 plasmid were digested with Eco RI (100 U) and Hind III $(100 \mathrm{U})$ in $100 \mu \mathrm{L}$ reaction mixtures following standard protocols. ${ }^{19}$ After purification, the insert was ligated with the vector using T4 DNA ligase. The pK1,6FucTDS expression vector constructed in this way was used to transform E. coli XL1-Blue MRF' competent cells that were then plated on LB agar plates containing $250 \mu \mathrm{g} \cdot \mathrm{mL}^{-1}$ ampicillin. Ten colonies were randomly selected and grown up for screening of positive clones. The plasmid was purified by the Ultra Clean Mini Plasmid Preparation kit (Mo Bio Laboratories, Inc.; Solana Beach, CA, USA) and characterized by restriction analysis. One positive clone was selected and used for protein expression.

\section{Expression of the truncated $\alpha$ 1,6-FucT}

The selected clone was grown up on $100 \mathrm{~mL}$ of LB medium containing $250 \mu \mathrm{g} \mathrm{mL}-1$ ampicillin at $37^{\circ} \mathrm{C}$ with shaking. When the cell growth reached an optical density at $600 \mathrm{~nm}\left(\right.$ O.D. $\left.{ }_{600}\right)$ of 0.5 , the temperature was switched to $30^{\circ} \mathrm{C}$ and the culture was induced with 1 mM IPTG. At different times (3, 5 and $24 \mathrm{~h}$ ) after induction samples were taken and analyzed by SDSPAGE $^{20}$ using $12,5 \%$ polyacrylamide in the separating gels.

\section{Activity and stability assays}

The culture broth was centrifuged $\left(3000 \mathrm{~g}, 30 \mathrm{~min}, 4^{\circ} \mathrm{C}\right)$, and the cell pellets were treated with lysozyme or with Bacterial Protein Extraction Reagent (B-PER ${ }^{\mathrm{TM}}$, Pierce; Rockford, IL, USA) to separate the soluble proteins from the inclusion bodies. The $\alpha 1,6$-FucT activity was assayed with a coupled enzymatic system, where the decrease of NADH absorbance at $340 \mathrm{~nm}$ is directly proportional to the release of GDP during the fucosyltransferase-catalyzed reaction..$^{9}$ The activity was measured at $25^{\circ} \mathrm{C}$ for $15 \mathrm{~min}$ in a final volume of $1 \mathrm{~mL}$, containing $12 \mathrm{mM}$ Hepes (pH 7.7), $13 \mathrm{mM} \mathrm{MnCl}_{2}, 50$ $\mathrm{mM} \mathrm{ClK}, 6.5 \mathrm{mM} \mathrm{MgCl}_{2}, 0.7 \mathrm{mM}$ PEP, $0.2 \mathrm{mM}$ NADH, 7.6 U pyruvate kinase, $18 \mathrm{U}$ lactate dehydrogenase, $100 \mu \mathrm{M}$ of chitobiose and $52 \mu \mathrm{M}$ of GDPFucose. Acceptor was omitted for the blank. The assay 
was initiated upon addition of $25 \mu \mathrm{L}(3.3 \mathrm{mU})$ of the truncated $\alpha 1,6-$ FucT preparation and the decrease in the absorbance at $340 \mathrm{~nm}$ was monitored. In order to make sure that the activity detected was due to the presence of the truncated enzyme, a control using $E$. coli extract harboring the plasmid pKK223-3 without insert was performed. Protein concentration was determined using the Bio-Rad (Hercules, CA, USA) Protein Assay kit, based on the Bradford dye-binding procedure. ${ }^{21}$ One unit of enzyme activity is defined as the amount that catalyzes the transfer of $1 \mu \mathrm{mol}$ of fucose from GDP-Fuc to chitobiose per min.

For the stability study the enzymes were kept at $4{ }^{\circ} \mathrm{C}$ in Tris- $\mathrm{HCl}$ buffer $50 \mathrm{mM}$, pH 8.0, containing $10 \mathrm{mM}$ EDTA.

\section{Kinetics analysis and acceptor specificity study}

Kinetic parameters were calculated for the donor substrate GDP-Fuc. The analysis conditions were essentially the same as described above except for the concentration of GDP-Fuc that was varied from 7 to $240 \mu \mathrm{M}$. Apparent kinetic parameters were obtained from the [s] $/ v$ against [s] plot. For the study of the acceptor specificity chitobiose was substituted by compounds described in Table 2.

\section{Acknowledgements}

We thank Drs. T. Ruiz-Argüeso and J. M. Palacios for the gift of Rhizobium sp. strain. We are indebted to Dr. J. Pérez-Gil for their comments about the kinetic analysis. A.B was supported by a postdoctoral fellowship from Comunidad de Madrid. This work was supported by the Spanish DGES (Grant PB96-0828) and Comunidad de Madrid (Grant 07B/0027/1999).

\section{References and Notes}

1. Lowe, J. B.; Stoolmann, L. M.; Nair, R. P.; Larsen, R. D.; Berhend, T. L.; Marks, R. M. Cell 1990, 63, 475. (b) Lasky, L. A. Science 1992, 258, 964. (c) Miller, D. J.; Macek, M. B. Nature 1992, 357, 589. (d) Varki, A. Glycobiology 1993, 3, 97. (e) Parker, W.; Lateef, J.; Everet, M. L.; Platt, J. L. Glycobiology 1996, 6, 499.

2. Leloir, L. F. Science 1971, 172, 1299.
3. (a) Ichikawa, Y.; Look, G. C.; Wong, C.-H. Anal. Biochem. 1992, 202, 215. (b) Öhrlein, R. Top. Curr. Chem. 1999, 200, 227. (c) Palcic, M. M. Curr. Opin. Biotechnol. 1999, 10, 616. 4. (a) Martin, S. L.; Edbrooke, M. R.; Hodgman, T. C.; van de Eijnden, D. H.; Bird, M. I. J. Biol. Chem. 1997, 272, 21349. (b) Ge, Z.; Chan, N. W. C.; Palcic, M. M.; Taylor, D. E. J. Biol. Chem. 1997, 272, 21357. (c) Gilbert, M.; Cunningham, A. M.; Watson, D. C.; Martin, A.; Richards, J. C.; Wakarchuk, W. W. Eur. J. Biochem. 1997, 249, 187. (d) Blixt, O.; van Die, I.; Norberg, T.; van de Eijnden, D. H. Glycobiology 1999, 9, 1061.

5. Bastida, A.; Fernández-Mayoralas, A.; Gómez Arrayás, R.; Iradier, F.; Carretero, J. C.; García-Junceda, E. Chem. Eur. J. 2001, 7, 2390.

6. (a) Cleland, J. L.; Wang, D. I. C. Bio/Technol. 1990, 8, 1274. (b) Cleland, J. L.; Randolph, T. W. J. Biol. Chem. 1992 , 267, 3147.

7. Hofmann, K.; Stoffel, W. Biol. Chem. Hoppe Seyler 1993, $347,166$.

8. Cserzo, M.; Wallin, E.; Simon, G.; von Heijne, G.; Elofsson, A. Prot. Eng. 1997, 10, 673.

9. (a) Gosselin, S.; Alhussaini, M.; Streiff, M. B.; Takabayashi, K.; Palcic, M. M. Anal. Biochem. 1994, 220, 92. (b) Fitzgerald, D. K.; Colvin, B.; Mawal, R.; Ebner, K. E. Anal. Biochem. 1970, 36, 43.

10. Cornish-Bowden, A. Fundamentals of Enzyme Kinetics; Portland: London, UK, 1995.

11. Quesada-Vincens, D.; Fellay, R.; Nasim, T.; Viprey, V.; Burger, U.; Promé, J.-C.; Broughton, W. J.; Jabbouri, S. J. Bacteriol. 1997, 179, 5087.

12. Quinto, C.; Wijfjes, A. H. M.; Bloemberg, G. V.; BlokTip, L.; López-Lara, I. M.; Lugtenberg, B. J. J.; ThomasOates, J. E.; Spaink, H. P. Proc. Natl. Acad. Sci. U.S.A. 1997, 94, 4336.

13. (a) Paulson, J. C.; Colley, K. J. J. Biol. Chem. 1989, 264, 17615. (b) Joziasse, D. H. Glycobiology 1992, 2, 271.

14. Wang, G.; Boulton, P. G.; Chan, N. W. C.; Palcic, M. M.; Taylor, D. E. Microbiology 1999, 145, 3245.

15. Oriol, R.; Mollicone, R.; Cailleau, A.; Balanzino, L.; Breton, C. Glycobiology 1999, 9, 323.

16. Breton, C.; Oriol, R.; Imberty, A. Glycobiology 1998, 8, 87.

17. Takahashi, T.; Ikeda, Y.; Tateishi, A.; Yamaguchi, Y.; Ishikawa, M.; Taniguchi, N. Glycobiology 2000, 10, 503.

18. (a) Aguilera, B.; Fernández-Mayoralas, A. Chem. Commun. 1996, 127. (b) Aguilera, B.; Fernández-Mayoralas, A.; Jaramillo, C. Tetrahedron 1997, 53, 127. (c) Aguilera, B.; Fernández-Mayoralas, A. J. Org. Chem. 1998, 63, 127. (d) Aguilera, B.; Jiménez-Barbero, J.; Fernández-Mayoralas, A. Carbohydr. Res. 1998, 308, 127.

19. Sambrook, J.; Fritsch, E. F.; Maniatis, T. Molecular Cloning. A Laboratory Manual; Cold Spring Harbor Laboratory: New York, 1989.

20. Laemmli, U. K. Nature 1970, 227, 680.

21. Bradford, M. M. Anal. Biochem. 1976, 72, 248. 